\title{
PENGINTEGRASIAN KURIKULUM, PERKEMBANGAN ANAK USIA DINI DAN HAK ANAK MELALUI MEDIA DI MASA PANDEMI
}

\author{
INTEGRATION OF THE CURRICULUM, EARLY CHILDHOOD DEVELOPMENT AND \\ CHILDREN'S RIGHTS THROUGH MEDIA IN PANDEMIC TIMES
}

\author{
${ }^{1)}$ Tesya Cahyani Kusuma, ${ }^{2)}$ Yessi Rifmasari, ${ }^{3)}$ Roza Dahlia \\ 1,2,3 PG-PAUD, STKIP ADZKIA \\ Email: yessi.rifmasari87@gmail.com
}

\begin{abstract}
ABSTRAK
Pelaksanaan pengabdian masyarakat ini dilatarbelakangi oleh keterbatasan guru dalam memberikan bahan pelajaran kepada siswa khususnya pada masa pandemi covid - 19. Pada masa pandemi, pelaksanaan pembelajaran dilaksanakan secara online sehingga guru merasa kurang maksimal dalam memberikan materi kepada siswa. Guru memerlukan media pembelajaran yang dapat memenuhi isi kurikulum sebagai upaya dalam penyampaian materi kepada siswa. Kenyataannya, tidak semua guru mampu merancang media pembelajaran yang sesuai dengan perkembangan anak usia dini. Selain itu, anak berhak memproleh pendidikan dan pengajaran walaupun dimasa pandemi covid. Melalui media audio visual dengan aplikasi kinemaster diharapkan dapat membantu guru dan menjadi solusi dalam pembelajaran saat ini. Hasilnya, media audio visual tersebut dapat membantu guru dalam menyampaikan materi terutama berkenaan dengan perkembangan nilai agama dan moral anak usia dini dengan indikator mengenal agama dan hari besar agama.
\end{abstract}

Kata Kunci : Kurikulum PAUD, Media Audio Visual, Nilai Agama dan Moral, Perkembangan Anak Usia Dini

\section{ABSTRACT}

The implementation of this community service is motivated by the limitations of teachers in providing learning materials to students, especially during the covid-19 pandemic. During the pandemic, the implementation of learning is carried out online so that teachers feel less than optimal in providing material to students. Teachers need learning media that can fulfill the curriculum content as an effort in delivering material to students. In fact, not all teachers are able to design learning media that are suitable for early childhood development. In addition, children have the right to receive education and teaching even during the covid pandemic. Through audio-visual media with the kinemaster application, it is hoped that it can help teachers and become a solution in current learning. As a result, the audio-visual media can assist teachers in delivering material, especially regarding the development of early childhood religious and moral values holidays.

Keywords: PAUD Curriculum, Audio Visual Media, Religious and Moral Values, Early Childhood Development

Diterima : 21-06-2021 Disetujui : 23-06-2021 Dipublikasikan: 30-06-2021 


\section{PENDAHULUAN}

Setiap manusia pasti membutuhkan informasi, kapan saja dan di mana saja, setiap individu harus mencari dan mendapatkan informasi baru. Apalagi saat ini dunia sedang mengalami kekacauan akibat pandemi yakni Covid-19, karena pandemi ini diimbau untuk melakukan social distancing dan physical distancing yang mengakibatkan masyarakat harus berada di rumah terus menerus dan dilarang berdekatan satu sama lain. Sehingga mau tidak mau harus melakukan aktivitas melalui online atau Work From Home (WFH). Kegiatan online ini dapat dilakukan dengan menggunakan alat atau media berupa laptop, smartphone, dan lain sebagainya, termasuk kegiatan belajar yang diberikan kepada anak usia dini pada usia 5-6 tahun. Karena kegiatan harus online kita harus memilih media yang cocok, tepat, dan menarik bagi anak usia dini dalam menyampaikan pesan belajar kepada anak- anak, selain itu juga harus memperhatikan perkembangan anak.

Istilah perkembangan berarti serangkaian perubahan progresif yang terjadi sebagai akibat dari proses kematangan dan pengalaman. Seperti yang dikatakan Van de Daele "perkembangan berarti perubahan secara kualitatif". Ini berarti bahwa perkembangan bukan sekedar penambahan beberapa sentimeter pada tinggi badan seseorang atau peningkatan kemampuan seseorang, melainkan suatu proses integrasi dari banyak struktur dan fungsi yang kompleks.

Salkind berpendapat bahwa perkembangan ialah suatu rangkaian perubahan progresif yang terjadi dalam suatu pola yang dapat diprediksi sebagai hasil interaksi antara faktor biologis dan lingkungan. Senada dengan pendapat tersebut, Woolfolk mengemukakan bahwa perkembangan ialah suatu perubahan adaptif secara teratur yang berlangsung sejak terjadinya konsepsi sampai meninggal dunia. Di samping itu, Santrock mengemukakan bahwa perkembangan merupakan suatu pola gerakan atau perubahan yang dimulai saat terjadinya konsepsi dan berlangsung melalui siklus kehidupan. Adapun Hurlock berpendapat bahwa perkembangan ialah serangkaian perubahan progresif yang terjadi sebagai akibat dari proses kematangan dan pengalaman.

Dari beberapa pengertian di atas dapat disimpulkan bahwa perkembangan ialah suatu proses perubahan secara berurutan dan progresif yang terjadi sebagai akibat kematangan dan pengalaman yang berlangsung mulai konsepsi sampai meninggal dunia.

Sejalan dengan itu, pemanfaatan media dalam pembelajaran dimasa pandemi selain memperhatikan perkembangan anak juga harus menempatkan hak anak sebagai prioritas yang utama untuk mencapai tujuan pembelajaran. Anak sebagai makhluk Allah SWT dan juga sebagai makhluk sosial sejak dalam kandungan sampai melahirkan mempunyai hak atas hidup dan merdeka serta mendapat perlindungan baik dari orang tua, keluarga, masyarakat, bangsa dan negara.Oleh karena itu tidak ada setiap manusia atau pihak yang boleh merampas hak atas hidup dan merdeka tersebut. Bila anak tersebut masih dalam kandungan orang tua dan orang tua tersebut selalu berusaha untuk menggugurkan anaknya dalam kandungannya, maka orang tua tersebut akan diproses hukum untuk mempertanggungjawabkan perbuatan yang melanggar hukum tersebut. Apalagi anak yang telah dilahirkan, maka hak atas hidup dan hak merdeka sebagai hak dasar dan kebebasan dasar tidak dapat dilenyapkan atau dihilangkan, tetapi harus dilindungi dan diperluas hak atas hidup dan hak merdeka tersebut. Oleh karena itu, untuk 
mengembangkan media pembelajaran dengan memperhatikan hal diatas, maka diperlukan kurikulum sebagai pedoman dalam menjawab permasalahan yang terjadi di masa pandemi ini. Pengintegrasian kurikulum dalam pembelajaran dengan mengakomodasi perkembangan dna hak anak dalam pembelajaran. Tujuan dilaksanakan pengabdian masyarakat ini adalah untuk meningkatkan kompetensi guru khususnya dalam memvariasikan pembelajaran dan melibatkan media sebagai penunjang dalam pembelajaran untuk mencapai tujuan yang diharapkan.

\section{METODE}

Pelaksanaan pengabdian masyarakat ini menggunakan metode demonstrasi yang dilaksanakan melalui pelatihan kepada guru guru Taman Kanak -Kanak tersebut. Sebelum mendemonstrasikan, diberikan pengantar tentang perkembangan anak usia dini, diiringi dengan hak anak dan pengintegrasian kurikulum sebagai pedoman dalam merancang pembelajaran. Terakhir, mendemonstrasikan media audio visual yang dirancang yang diambil pada salah satu metode pengembangan anak usia dini, diantaranya nilai agama dan moral dan kognitif anak usia dini. Media yang ditrancang untuk nilia moral dan agama menggunakan aplikasi kinesmaster dengan indikator mengenal hari - hari besar agama dan agama yang dianut. Selanjutnya, untuk pengembangan kognitif anak usia dini menggunakan software power point dengan indikator mengenal angka 1-10. Media yang dirancang bersifat audio visual dan dioperasikan offline (tidak harus terhubung dengan jaringan internet).

Dari pelaksanaan pengabdian masyarakat tersebut, data diolah dengan menggunakan jenis penelitian kuasi eksperimen pada kelas kontrol dan kelas eksperimen untuk melihat penerapan media tersebut berdasarkan indikator yang telah ditentukan.

\section{HASIL DAN PEMBAHASAN}

Berdasarkan hasil penelitian dan analisis data yang telah dijelaskan, perlu dibahas lebih lanjut penerapan media pembelajaran audio visual dalam meningkatkan nilai-nilai keagamaan dan moral anak sesuai dengan indikator yang telah ditentukan, yaitu: 1) mengetahui agama yang dianut, 2) mengetahui hari besar agama.

Penerapan media pembelajaran audio visual sangat berpengaruh dalam meningkatkan nilai-nilai keagamaan dan moral anak, yang pertama adalah mengetahui agama yang dianut, terkait teori tersebut menurut Hasan (2016:26) mengatakan keunggulan media audio visual bahwa pemakainya tidak membosankan. Penerapan media pembelajaran yang tidak membosankan berarti media pembelajaran yang digunakan menarik bagi anak-anak dan hal ini dapat mempermudah anak menerima pesan belajar seperti mengetahui agama yang dianut oleh anak-anak dapat dengan mudah mengetahui agama apa saja yang ada di Indonesia.

Indikator kedua adalah mengetahui hari besar agama, Menurut Arsyad (2015:141) Media audio dan audio visual adalah bentuk media pembelajaran yang murah dan terjangkau. Ini menunjukkan bahwa media audio visual dapat menampilkan pesan yang memberikan motivasi kepada anak, seperti menampilkan video yang memberikan pesan pembelajaran tentang mengetahui tentang hari besar keagamaan. Anak-anak akan dengan mudah mengingat pesan pembelajaran yang dikirimkan. melalui video yang memiliki elemen suara dan gambar seperti video yang dirancang menggunakan aplikasi master kine tentang hari libur keagamaan. 
Jika penerapan media audio visual dimaksimalkan dalam proses pembelajaran, maka akan memberikan kemudahan bagi anak-anak untuk dapat merangsang perkembangan nilai-nilai keagamaan dan moral mereka. Selain itu, juga memberikan kemudahan bagi guru dalam menyampaikan materi terutama terkait pembelajaran moral.

Efek dari penerapan media audio visual dalam pembelajaran "nilai-nilai agama dan moral" sangat tepat dalam meningkatkan moral anak dengan anak ini akan mendapatkan pemahamannya sendiri tentang pesan moral yang diperoleh melalui film, cerita, baik yang dipahami melalui pendengaran atau penglihatan. Efek dari penerapan media audio visual dalam pembelajaran "nilai-nilai agama dan moral" sangat tepat dalam meningkatkan moral anak dengan anak ini akan mendapatkan pemahamannya sendiri tentang pesan moral yang diperoleh melalui film, cerita, baik yang dipahami melalui pendengaran atau penglihatan.

Sebagaimana dijelaskan oleh Fithri, dkk (2017:68) penggunaan media audio visual yang diterapkan oleh guru sebagai upaya meningkatkan perkembangan nilainilai keagamaan dan moral anak harus dirancang sedemikian rupa baik dalam hal pemilihan cerita maupun suara sebagai pendukung sehingga dapat menarik minat anak untuk mengikuti pembelajaran. Penggunaan media ini terus digunakan sebagai upaya untuk meningkatkan perkembangan anak setiap putarannya. Dari pendapat para ahli ini terkait penelitian ini, para peneliti akan menunjukkan media pembelajaran kepada anak-anak berusia 5-6 tahun untuk melihat pengaruh penerapan media dan bertujuan untuk meningkatkan perkembangan nilai-nilai agama dan moral anak-anak.
Dengan memanfaatkan media ini, diharapkan penyajian materi kepada anakanak akan disampaikan secara optimal. Selain itu, media ini dalam batas-batas tertentu juga dapat menggantikan peran dan tugas guru. Dalam hal ini guru tidak bertindak sebagai penyampaian materi tetapi beralih ke fasilitator yaitu memberikan kemudahan bagi anak-anak untuk belajar. Adapun kendala yang ditemukan pada saat penelitian, yaitu keterbatasan waktu yang diberikan, hal ini terjadi karena kegiatan belajar anak selama pandemi COVID-19 tidak seperti biasanya, namun penelitian yang dilakukan tetap berhasil.

Tabel 1

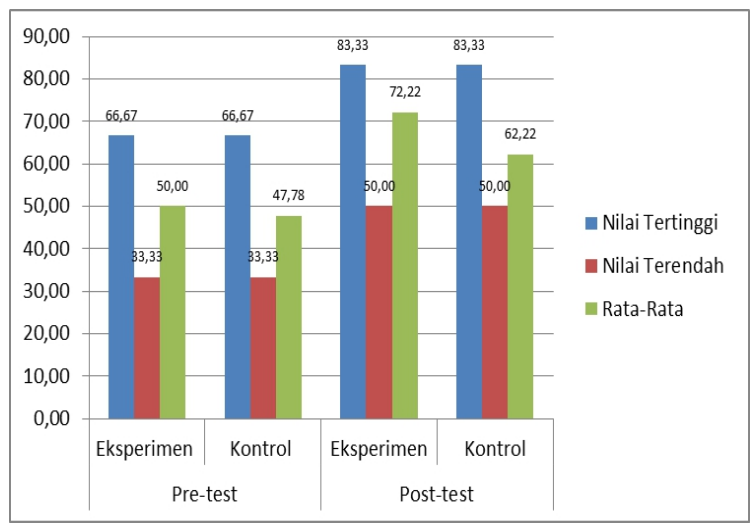

Tabel 1. Histogram Pengujian Hipotesis Pre-Test dan Post-Test di Kelas Eksperimen dan Kelas Kontrol

Proses pembelajaran nilai-nilai agama dan moral dengan menerapkan media audio visual pada anak usia 5-6 tahun yang melibatkan anak secara langsung dalam penerapannya, anak tidak merasa bosan mengikuti proses pembelajaran sehingga nilai-nilai agama dan moral anak dapat meningkat. Anak-anak melakukan pembelajaran tanpa tekanan dan terus bersemangat mengikuti proses pembelajaran, media audio visual sangat berpengaruh untuk 
meningkatkan nilai-nilai agama dan moral anak-anak.

\section{Tabel 2}

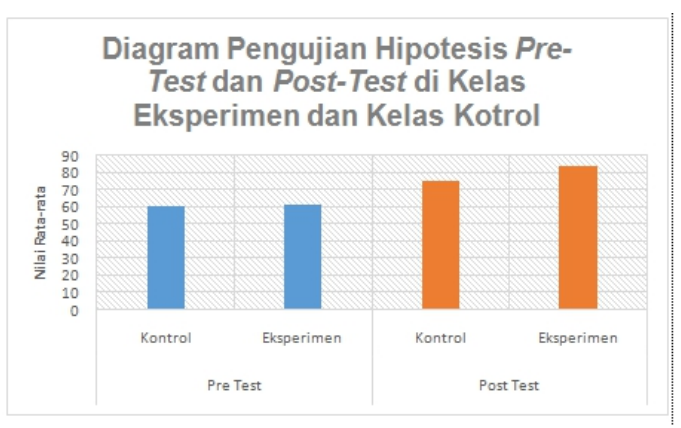

Tabel 2. Diagram Pengujian Hipotesis PreTest dan Post-Test di Kelas Eksperimen dan Kelas Kotrol

Hasil analisis data yang diperoleh, menunjukan bahwa ada pengaruh kemampuan berhitung anak pada kelas eksperimen dengan menggunakan media audio visual pada kemampuan kognitif anak. Berdasarkan Undang-undang Nomor 20 Tahun 2003 tentang Sistem Pendidikan Nasional berkaitan dengan Pendidikan Anak Usia Dini tertulis pada pasal 28 ayat 1 yang berbunyi "Pendidikan Anak Usia Dini didelenggarakan bagi anak sejak lahir sampai dengan enam tahun dan bukan merupakan persyaratan untuk mengikuti pendidikan dasar". Selanjutnya pada Bab 1 ayat 14 ditegaskan bahwa Pendidikan Anak Usia Dini adalah suatu pembinaan yang ditujukan kepada anak sejak lahir sampai dengan usia enam tahun yang dilakukan melalui pemberian rangsangan pendidikan untuk membantu pertumbuhan dan perkembangan jasmani dan rohani agar anak memiliki kesiapan dalam memasuki pendidikan lebih lanjut.
Pendidikan Anak Usia Dini Pendidikan Anak Usia Dini merupakan salah satu bentuk penyelenggaraan pendidikan yang menitik beratkan pada peletakan dasar kearah pertumbuhan dan perkembangan fisik (koordinasi motorik halus dan kasar), kecerdasan (daya pikir, daya cipta, kecerdasan emosi, kecerdasan spiritual), sosial emosional (sikap dan prilaku serta beragama, bahasa dan komunikasi, sesuai dengan keunikan dan tahap-tahap perkembangan yang dilalui oleh anak usia dini. Pendidikan bagi anak usia dini adalah pemberian upaya untuk menstimulasi, membimbing, mengasuh, dan pemberian kegiatan pembelajaran yang akan menghasilkan kemampuan dan keterampilan anak. Pendidikan abagia anak usia dini merupakan sebuah pendidikan yang dilakuakan pada anak yang baru lahir sampai dengan delapan tahun. Pendidikan pada tahap ini memfokuskan pada physical, intelligence/cognitive, emotional, social education.

Sesuai dengan keunikan dan pertumbuhan anak usia dini maka penyelenggaraan pendidikan bagi anak usia dini disesuaikan dengan tahap-tahap perkembangan yang dilalui oleh anak usia dini. Upaya PAUD bukan hanya dari sisi pendidikan saja, tetapi termasuk upaya pemberian gizi dan kesehatan anak sehingga dalam pelaksanaan PAUD dilakukan secara terpadu dan komprehensif.

\section{Kurikulum PAUD}

Kurikulum sebagai program pendidikan berfungsi sebagai pedoman 
umum dalam penyelenggaraan sistem pendidikan . Menurut Sukirman, Dadang (1.1) dalam modul Universitas Terbuka mengatakan Kurikulum memuat garis - garis besar program kegiatan yang harus dilakukan dalam setiap penyelenggaraan pendidikan antara lain tujuan pendidikan, pokok - pokok materi, bentuk kegiatan dan kegiatan evaluasi . Pendekatan kurikulum yang digunakan pada setiap lembaga pendidikan, memiliki fokus yang berbeda- beda, mengingat tuntutan dan kebutuhan dalamsetiap aspek yang terus berkembang dan juga berpengaruh pada pelaksanaan kurikulum . Dua pokok unsur utama kurikulum (1) isi kurikulum (2) tujuan utama pendidikan atau kurikulum. SISDIKNAS No. 20 Tahun 2003 Kurikulum adalah seperangkat rencana dan pengaturan mengenai tujuan, isi, dan bahan pelajaran serta cara yang digunakan sebagai pedoman penyelenggaraan kegiatan pembelajaran untuk mencapai tujuan pendidikan tertentu (Bab I Pasal 1). Salah satu isi dari kurikulum yang dapat diintegrasikan dalam pembelajaran adalah dengan menggunakan tema. Menurut Rakimahwati (2012:18) dalam bukunya yang berjudul Konsep Pembelajaran Tematik Untuk Anak Usia Dini mengatakan pembelajaran di TK berorientasi pada anak itu sendiri. Karena tema memberikan pengalaman langsung dengan objek-objek yang riil bagi anak untuk menilai dan memanipulasinya. Menurut Rudianto dan Nugraha, Ali (10.1) dalam modul Universitas Terbuka mengatakan Kegiatan yang terprogram menjadi agenda dan dirancang dalam silabus guru, baik untuk jangka waktu yang pendek maupun panjang, yaitu untuk satu hari, satu minggu, satu bulan, maupun lebih lama lagi. Komponen Kurikulum harus dapat merangsang pengalaman-pengalaman yang dibutuhkan anak dan mampu mendorong kegiatan belajar anak dalam aspek-aspek jasmani (fisik), sosial, emosioanal, dan intelektual dengan tujuan agar guru merancang lingkungan belajar, sehingga anak dapat bereksplorasi aktif, berinteraksi dengan teman sebaya, guru dan alat- alat pelajaran. Memberikan kesempatan pada anak untuk melakukan perbuatanperbuatan sosial yang positif, seperti kerjasama, membantu orang tua, dan mendengarkan keluhan-keluhan orang lain.

Kurikulum bagi orang tua dapat dijadikan sebagai acuan untuk berpartisipasi dalam membimbing anak-anaknya sehingga pengalaman belajaran yang diberikan oleh orang tua sesuai dengan pengalaman belajar yang diterima anak dikurikulum bagi masyarakat dapat di jadikan sarana penghubung antara sekolah dengan lingkungan setempat. Dengan memberikan pemahaman kepada masyarakat mengenai kurikulum sekolah dengan lingkungan setempat. Dngan memberikan pemahaman kepada masyarakat mengenai kurikulum sekolah, akan sangat bermanfaat bagi sekolah karena masyarakat dapat ikut memberikan kritik dan saran yang membantu dalam rangka menyempurnakan program pendidikan disekolah agar dapat melahirkan generasi yang sesuai dengan kebutuhan masyarakat. Termasuk dalam hal ini adalah muatan lokal dalam kurikulum yang berisi program pembelajaran berwawasan lingkungan.

\section{Media Audio Visual}

Pembelajaran dengan menggunakan media audio visual berkaitan dengan indera penglihatan dan pendengaran sehingga dapat mengefektifkan kemampuan alat indera anak dan anak dengan mudah menangkap sebuah materi yang diangkan dalam video tersebut. Pemilihan media juga harus disesuaikan dengan materi apa yang ingin disampaikan, tujuan apa yang ingin dicapai, 
karakteristik peserta didik, karakteristik media yang dipilih, Waktu pembuatan dan penayangan, biaya, dan suasana kelas. Hal ini bertujuan untuk tercapainya tujuan pembelajaran. Salah satu media pembelajaran yang dapat digunakan oleh guru ialah media audio visual. Menurut Sanjaya, Wina (2008:211) mengatakan Media audio visual merupakan media yang dapat menyajikan gambar bergerak, warna dan disertai penjelasan berupa tulisan dan suara. edia Audio-Visual ini mengandalkan 2 indera manusia sekaligus yakni pendengaran (Audio) dan Penglihatan (Visual). Alat bantu ini juga merupakan alat yang dipergunakan dalam situasi belajar untuk membantu kata serta tulisan dapat menularkan pengetahuan, ide serta sikap peserta didik.

\section{SIMPULAN}

Memilih media atau alat peraga yang tepat, yang sesuai dengan materi akan sangat penting untuk membantu meningkatkan pemahaman anak sehingga nantinya bisa mendapatkan hasil yang baik. Media audio visual adalah media instruksional modern yang sesuai dengan perkembangan zaman, yaitu kemajuan ilmu pengetahuan dan teknologi. Seperti namanya media ini adalah kombinasi audio (melalui pendengaran) dan visual (melalui penglihatan).

Dengan memanfaatkan media ini, diharapkan penyajian materi kepada anakanak akan disampaikan secara optimal. Selain itu, media ini dalam batas-batas tertentu juga dapat menggantikan peran dan tugas guru. Dalam hal ini guru tidak bertindak sebagai penyampaian materi tetapi beralih ke fasilitator yaitu memberikan kemudahan bagi anak-anak untuk belajar. Melalui media ini guru dapat menampilkan dongeng atau cerita yang dikemas dalam sebuah film dengan tema nilai-nilai agama dan moral, hal ini bertujuan agar anak dapat melihat, mendengar, memahami, dan kemudian mencontoh hal-hal baik seperti berperilaku baik kepada orang lain, menghormati orang yang lebih tua, mencintai orang yang lebih muda, suka membantu tanpa pamrih, berperilaku/ menjaga sopan santun, jujur untuk tidak berbohong, tidak mengambil hal-hal yang bukan miliknya, dan sebagainya. Selain itu juga, melalui media dapat membantu mengembangkan kognitif anak terutama dalam hal mengenal angka dan berhitung. Peningkatan kompetensi guru melalui pemanfaatan media pembelajaran diharapkan dapat menciptakan pembelajaran yang lebih bervariasi lagi dan lebih bermakna.

\section{DAFTAR PUSTAKA}

Azhar Arsyad. 2013. Media Pembelajaran PT. Raja Grafindo Persada Jakarta

Depdiknas, Panduan Mengajar di TK/RA (Jakarta: Depdiknas,2005)

Elizabeth B. Hurlock, Psikologi Perkembangan (Jakarta: Penerbit Erlangga, 2009)

M. Ramli, Pendampingan Perkembangan Anak Usia Dini (Jakarta: Depdiknas, 2004)

Rudianto, Nugraha, Ali. 2016. Modul 10 Perancangan Kegiatan Pengembangan di TK. Ruang Baca Virtual UT. http://www.pustaka.ut.ac.id/reader/index.php? subfolder $=$ PGTK2403/\&doc $=$ M10.pdf

Sanjaya, Wina. 2008. Perencanaan dan Design Sistem Pembelajaran. Jakarta: Prenada Media Group

Undang-undang nomor 39 tahun 1999 tentang hak asasi manusia;

Wiwien Dinar Pratisti, Psikologi Anak Usia Dini (Jakarta: PT Indeks, 2008),h. 29 